\title{
EARTHWORM POPULATIONS SAMPLED USING COLLECTION METHODS IN ATLANTIC FORESTS WITH Araucaria angustifolia
}

\author{
Dilmar Baretta; George Gardner Brown²; Samuel Wooster James³; Elke Jurandy Bran \\ Nogueira Cardoso ${ }^{4 *}$ \\ ${ }^{1}$ USP/ESALQ - Programa de Pós-Graduação em Solos e Nutrição de Plantas. \\ ${ }_{3}^{2}$ Embrapa Florestas, Estrada da Ribeira Km. 111, C.P. 319 -83411-000 - Colombo, PR - Brasil. \\ ${ }^{3}$ University of Kansas - Natural History Museum and Biodiversity Research Center, 1345 - 66045 - Lawrence, \\ $K S-U S A$. \\ ${ }^{4}$ USP/ESALQ - Depto. de Ciência do Solo, C.P. 9 -13418-900 - Piracicaba, SP - Brasil. \\ *Corresponding author <ejbncard@esalq.usp.br>
}

ABSTRACT: Araucaria angustifolia, also known as the Paraná Pine is an endangered tree species in Brazil and little is known of the diversity of soil invertebrates inhabiting these forests. Therefore, the present study was set up to evaluate the biomass and diversity of earthworms in natural and reforested Araucaria plots, impacted or not by fire, and to identify the most efficient earthworm collection method. Four study areas included: native forest with Araucaria (NF); Araucaria reforestation (R); Araucaria reforestation submitted to an accidental fire (RF); and native grass pasture with native Araucaria and submitted to an intense accidental fire (NPF). Five soil samples containing the earthworm community were taken in a 0.3 ha area in each of the forest sites, close to five Araucaria trees selected at random. Three collection methods were tested: application of dilute Formol $(0.5 \%)$ to the soil surface, handsorting of small $(25 \times 25 \mathrm{~cm})$ or large $(40 \times 40 \mathrm{~cm})$ monoliths. Five earthworm species were found: the native Glossoscolex sp.1, Glossoscolex sp.2, Glossoscolex bondari and Urobenus brasiliensis (Glossoscolecidae), and the exotic Amynthas corticis (Megascolecidae). Formol was more efficient for collecting A. corticis, found in much higher abundance and biomass in NF than in the other areas. Larger handsorted samples were more efficient for capturing Glossoscolex species, mainly present in RF and NPF. For adequate characterization of earthworm abundance and biomass in these Araucaria forests, both the Formol and the larger monolith methods are recommended.

Key words: Oligochaeta, biodiversity, burning, native and exotic species, bioindicators

\section{POPULAÇÕES DE MINHOCAS AMOSTRADAS USANDO MÉTODOS DE COLETA EM FLORESTA ATLÂNTICA COM Araucaria angustifolia}

RESUMO: Araucaria angustifolia, também conhecida como Pinheiro do Paraná é uma espécie de árvore ameaçada de extinção no Brasil e pouco se conhece sobre a diversidade de invertebrados que habitam os solos destas florestas. O presente estudo teve o objetivo de avaliar, em florestas com araucária naturais e reflorestadas impactadas ou não pela queima acidental, a diversidade e a biomassa de minhocas, além de identificar o método mais eficiente para coletar estes animais. As áreas estudadas incluem: floresta nativa com araucária $(\mathrm{NF})$; reflorestamento de araucária $(\mathrm{R})$; reflorestamento de araucária submetido a incêndio acidental (RF); e campo nativo com araucárias nativas e ocorrência de incêndio (NPF). Em cada floresta, cinco amostras de solo para avaliação da comunidade de minhocas foram coletadas em 0,3 ha, perto de cinco árvores de araucária selecionadas ao acaso. Foram testados três métodos: aplicação de Formol diluído (0,5\%) na superfície do solo; escavação e triagem manual de monólitos pequenos $(25 \times 25 \mathrm{~cm})$ ou maiores $(40 \times 40 \mathrm{~cm})$. Foram encontradas cinco espécies de minhocas, as nativas Glossoscolex sp.1, Glossoscolex sp.2, Glossoscolex bondari e Urobenus brasiliensis (Glossoscolecidae), e a exótica Amynthas corticis (Megascolecidae). Formol foi mais eficiente para coletar A. corticis espécie encontrada em maior abundância e biomassa fresca total em NF do que nas outras áreas. A triagem manual de amostras de solo maiores foi mais eficiente para capturar as espécies de Glossoscolex, presentes principalmente em RF e NPF. Formol e a triagem manual de monólitos maiores são recomendados para caracterizar a abundância e biomassa de minhocas nas florestas com araucárias. Palavras-chave: Oligochaeta, biodiversidade, queima, espécies nativas e exóticas, bioindicadores 


\section{INTRODUCTION}

Araucaria angustifolia (Bertoloni) Otto. Kuntze., also known as the Paraná pine, is a gymnosperm plant that belongs to the Araucariaceae family, and is the most important tree in the Mixed Subtropical Ombrophilous (Araucaria) forest. This forest originally covered about $200,000 \mathrm{~km}^{2}$ (Guerra et al., 2002) in Brazil. Today only $3 \%$ of this forest remains intact in the State of São Paulo (SP), at sites with elevations ranging from 500 to 1.600 meters, between $21^{\circ}$ and $30^{\circ} \mathrm{S}$ (Hueck, 1972).

Human interference and accidental fires in Araucaria forests in SP caused directly or indirectly by humans contribute to the extinction of this plant (classified as endangered) and could negatively affect the populations and diversity of soil invertebrates living in them. However, there are little available data on the effect of human interventions on these organisms in SP.

Although studies involving soil fauna have substantially increased in recent decades in Brazil and the world (Baretta et al., 2006; James \& Brown, 2006) owing to a growing interest for an understanding of the processes by which these organisms take part in various ecosystems, there are still methodological challenges to be overcome in these studies (Edwards, 1991). In this respect, a number of factors complicate the evaluation of soil animal biodiversity, such as: environmental and soil heterogeneity, difficulty in extracting these animals (Raw, 1959; Decaëns \& Rossi, 2001) and determining the ideal sample size to estimate number of species per unit area (Giller et al., 1997; Ekschmitt, 1998) and representativeness of the sample (Dickey \& Kladivko, 1989).

Sampling methods often under or overestimate the density and diversity of soil organisms, and the "Tropical Soil Biology and Fertility" method (TSBF) (Anderson \& Ingram, 1993), frequently underestimates the abundance of both smaller (e.g., ants, termites, centipedes, pillbugs) and larger (e.g., big earthworms) animals that do not even fit within a sample, and may be cut when the monolith is collected (Caballero, 1976; Lavelle et al., 1981; Jiménez et al., 2006). Therefore, the adoption of a single sampling method may not be effective to extract the abundance and richness of earthworm species from a given site (Dikey \& Kladivko, 1989; Joschko et al., 2006), such as when these species remain in deeper soil layers most of the time (Chan \& Munro, 2001; Lavelle \& Spain, 2001), or during the dry season.

The study of earthworm populations living in Araucaria forests may be important to understand soil processes in these ecosystems, since earthworms are major players in the decomposition and mineralization of organic matter and in the generation and maintenance of soil structure (Lavelle \& Spain, 2001). Furthermore, earthworms can be used as bioindicators of disturbance as well as of soil quality (Paoletti, 1999; Joschko et al., 2006). Therefore, the present study was conducted in order to evaluate the earthworm density, diversity and biomass, and to identify the most effective method to collect these animals in natural forest areas and in areas reforested with Araucaria, impacted or not by fire.

\section{MATERIAL AND METHODS}

The study was conducted in the Campos do Jordão county, SP, in four areas with A. angustifolia, belonging to the Campos do Jordão State Park, located

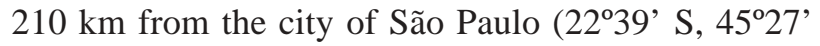
$\mathrm{W})$, at a mean elevation of $1.519 \mathrm{~m}$. The sites were located in an area with gently rolling topography, and a mean slope of $0.1702 \mathrm{~m} \mathrm{~m}^{-1}$. The soil in the four Araucaria forest areas was classified as a clayey-textured Typic Hapludox (Table 1), and the climate in the region is defined as subtropical (upland), mesothermal, and humid (Köppen's Cfb). Most precipitation falls in the summer, and $>240 \mathrm{~mm}$ may fall in February, while in September (driest month) rainfall amounts to approximately $90 \mathrm{~mm}$. Mean monthly temperature ranges from $17.5^{\circ} \mathrm{C}$ in February to $11.5^{\circ} \mathrm{C}$ in June (Moreira et al., 2006).

Table 1 - Soil chemical characteristics in natural forest (NF), introduced forest (R), forest impacted-by-fire (RF) and native grass pasture with Araucaria trees submitted to an intense accidental fire in September 2004 (NPF). Campos do Jordão, SP, Brazil.

\begin{tabular}{|c|c|c|c|c|c|c|c|}
\hline Area & $\begin{array}{c}\mathrm{pH} \mathrm{CaCl} \\
0.01 \mathrm{~mol} \mathrm{~L}^{-1}\end{array}$ & $\mathrm{OM}^{1}$ & $P(r e s i n)$ & K & $\mathrm{Ca}$ & $\mathrm{Mg}$ & $\mathrm{H}+\mathrm{Al}$ \\
\hline & & $\mathrm{g} \mathrm{dm}^{-3}$ & $\mathrm{mg} \mathrm{dm}{ }^{-3}$ & \multicolumn{4}{|c|}{-1} \\
\hline NF & 3.7 & 158.4 & 9.8 & 3.4 & 3.0 & 2.3 & 209.1 \\
\hline $\mathrm{R}$ & 3.9 & 139.7 & 3.9 & 2.2 & 1.5 & 1.0 & 175.7 \\
\hline RF & 3.9 & 160.3 & 8.4 & 3.0 & 2.3 & 1.5 & 198.0 \\
\hline NPF & 3.9 & 42.4 & 3.5 & 3.1 & 2.0 & 1.5 & 96.0 \\
\hline
\end{tabular}

${ }^{\mathrm{I}} \mathrm{OM}=$ organic matter (Walkey-Black Method). 
The four forests with Araucaria selected for the study were: a native, climax forest, with predominance of Araucaria trees, and low anthropic interference (NF); a reforested Araucaria plot planted in 1959 (R); a reforested Araucaria plot planted in 1959, submitted to an intense accidental fire in July 2001 (RF); and a natural pasture grazed by cattle containing native Araucaria trees (NPF), submitted to an intense accidental fire in September 2004. All sample sites were located in a toposequence at similar elevation. The native forest (NF) contained mostly large Araucaria trees and other shrubby, herbaceous, and arboreal species belonging to various native families. Site $\mathrm{R}$ had several Podocarpus lambertii Klotz trees, but a predominance of Araucaria trees. Due to the fire, RF had fewer Araucaria trees and a predominance of Aristida longiseta (grass) and Braccharis trimera (Compositae).

Five soil samples to evaluate the earthworm community were taken in 0.3 ha areas selected at random in each of the four sites, close to five Araucaria trees. Distance between sampling points was approximately 10 meters. In August 2005 three collection methods were tested: the application of 20 liters of dilute $(0.5 \%)$ formaldehyde (Formol) on a $1 \mathrm{~m}^{2}$ soil surface (Raw, 1959); handsorting of small $(25 \times 25 \mathrm{~cm})$ (TSBF), or larger $(40 \times 40 \mathrm{~cm})$ soil monoliths, both taken to a $0-0.3 \mathrm{~m}$ depth. Larger sample units and Formol were employed because a large anecic species (Glossoscolex giganteus Leuckart, 1836) had been reported in these areas (Michaelsen, 1926). Soil chemical characteristics (Table 1) were evaluated from three subsamples, collected around each randomly selected Araucaria tree, from a soil layer of $0-0.2 \mathrm{~m}$. The samples were analyzed according to the methodology described by Raij et al. (2001).

Earthworms appearing on the soil surface with the formalin applications were placed in $20 \%$ alcohol for approximately 5 minutes to be anesthetized and killed. The earthworms were thereafter preserved in $4 \%$ formaldehyde. In the TSBF and larger monolith samples, the earthworms were handsorted from the soil. In the laboratory, adult earthworms were identified to the genus (imatures) or the species level; identification at the species level was made using a stereoscopic microscope of $100 \times$ magnification. Total fresh biomass $\left(\mathrm{g} \mathrm{m}^{-2}\right)$ was obtained by washing the earthworms in running water, and drying them with a paper towel in the open air for three minutes.

Earthworm abundance per square meter (number of individuals $\left.\mathrm{m}^{-2}\right)$ and total fresh biomass $\left(\mathrm{g} \mathrm{m}^{-2}\right)$ in the areas were submitted to analysis of variance (two-way ANOVA), using the SAS version 6.2 statistical program (SAS Institute, 1996), and means were compared by the LSD test $(P<0.05)$. Due to vari- ance heterogeneity (high presence of zero values), the abundance and biomass data were Log transformed. A multivariate cluster analysis was also performed by the complete linkage (furthest neighbor) method (Everitt, 1993; Jongman, 1995). In this case, the "Euclidean distance" (Frakes \& Yates, 2000) between the number of earthworms of each species captured per $\mathrm{m}^{-2}$ was taken as a similarity measurement, using the STATISTICA 6.0 program (StatSoft Inc., 2001). Additionally, earthworm abundance and total fresh biomass were used to obtain the gradient length. Because this length was smaller than three (linear response), the principal components analysis (PCA) was chosen, via the CANOCO version 4.0 software program (Ter Braak, 1986; Ter Braak \& Smilauer, 1998).

\section{RESULTS AND DISCUSSION}

The soils had low base saturation and are acidic at all sites. At NF, however, the soil presented higher $\mathrm{P}, \mathrm{K}, \mathrm{Ca}$, and $\mathrm{Mg}$ contents than the other areas (Table 1).

\section{Abundance of the earthworm species}

Combining the three methods, five earthworm species were found, belonging to two families and three genera. The most abundant earthworm was an exotic species, Amynthas corticis (Kinberg, 1867) (Megascolecidae). The remaining species (all native), Glossoscolex sp.1, Glossoscolex sp.2, Glossoscolex bondari (Michaelsen, 1926) and Urobenus brasiliensis (Benham, 1887) (Glossoscolecidae), were all less abundant (Table 2).

Earthworm abundance varied from 0 to 20 individuals $\mathrm{m}^{-2}$, following a descending order in the sample sites RF > NF > R > NPF, although the order depended on the method employed (Table 2). However, the collection method influenced earthworm diversity and abundance, and the magnitude of response varied according to the method employed, and the abundance of species present in each sample site.

Very few earthworms were extracted from the $\mathrm{R}$ and NPF areas by the Formol method (Table 2). This method is only effective for some earthworm species that are active on the soil surface, such as A. corticis. There was a low frequency of Amynthas in these systems, and other species present were not collected with formalin application. Baker (1985) tested the effectiveness of five dilute formaldehyde rates $(0.07,0.11$, $0.22,0.44$ and $0.66 \%$ ) as compared to the manual collection method (using a $0.25 \mathrm{~m}^{2}$ quadrant) to extract earthworms, and verified that the $0.44 \%$ concentration ( similar to the one tested in the present study) was the most effective to extract earthworm species more 
Table 2 - Abundance and biomass (Mean \pm SD: Standard deviation) of earthworms collected in August 2005, using the Formol $(0.5 \%)$, small $(25 \times 25 \mathrm{~cm})(\mathrm{TSBF})$ and large Monolith $(40 \times 40 \mathrm{~cm})$ methods, in a natural forest (NF), introduced forest (R), forest impacted-by-fire (RF) and native grass pasture with Araucaria trees submitted to an intense accidental fire in September 2004 (NPF). Campos do Jordão State Park, SP, Brazil. Mean of five replicates.

\begin{tabular}{|c|c|c|c|c|c|c|}
\hline \multicolumn{2}{|l|}{ Earthworm species } & $\mathrm{NF}$ & & $\mathrm{R}$ & $\mathrm{RF}$ & $\mathrm{NPF}$ \\
\hline & & \multicolumn{5}{|c|}{ Formol $(0.5 \%)$} \\
\hline \multirow[t]{2}{*}{ A. corticis } & No. Indiv. $\mathrm{m}^{-2}$ & $8.0( \pm 4.2)$ & 0.6 & $( \pm 0.3)$ & $3.4( \pm 1.4)$ & $0.2( \pm 0.1)$ \\
\hline & Biomass* & $11.5( \pm 5.3)$ & 0.3 & $( \pm 0.1)$ & $2.8( \pm 0.8)$ & $0.1( \pm 0.0)$ \\
\hline \multirow[t]{2}{*}{ Glossoscolex sp. 1} & No. Indiv. $\mathrm{m}^{-2}$ & 0 & 0.4 & $( \pm 0.1)$ & $0.2( \pm 0.1)$ & $0.4( \pm 0.2)$ \\
\hline & Biomass & 0 & 0.2 & $( \pm 0.1)$ & $0.2( \pm 0.1)$ & $0.1( \pm 0.0)$ \\
\hline \multirow{2}{*}{ Glossoscolex sp. 2} & No. Indiv. $\mathrm{m}^{-2}$ & $0.2( \pm 0.1)$ & & 0 & 0 & 0 \\
\hline & Biomass & $0.3( \pm 0.1)$ & & 0 & 0 & 0 \\
\hline \multirow[t]{2}{*}{ G. bondari } & No. Indiv. $\mathrm{m}^{-2}$ & 0 & & 0 & $0.2( \pm 0.1)$ & 0 \\
\hline & Biomass & 0 & & 0 & $0.2( \pm 0.1)$ & 0 \\
\hline \multirow[t]{2}{*}{ U. brasiliensis } & No. Indiv. $\mathrm{m}^{-2}$ & $0.2( \pm 0.1)$ & 0.2 & $( \pm 0.1)$ & 0 & 0 \\
\hline & Biomass & $0.3( \pm 0.1)$ & 0.1 & $( \pm 0.0)$ & 0 & 0 \\
\hline \multirow[t]{2}{*}{ Total No. earthworms $\mathrm{m}^{-2}$} & & $8.4 \mathrm{a}$ & & $1.2 \mathrm{~b}$ & $3.8 \mathrm{ab}$ & $0.6 \mathrm{~b}$ \\
\hline & & \multicolumn{5}{|c|}{ Monoliths $(25 \times 25 \mathrm{~cm})(\mathrm{TSBF})$} \\
\hline \multirow[t]{2}{*}{ A. corticis } & No. Indiv. $\mathrm{m}^{-2}$ & $6.4( \pm 3.6)$ & & 0 & 0 & 0 \\
\hline & Biomass* & $0.1( \pm 0.0)$ & & 0 & 0 & 0 \\
\hline \multirow[t]{2}{*}{ Glossoscolex spp.** } & No. Indiv. $\mathrm{m}^{-2}$ & 0 & & 0 & $3.2( \pm 1.1)$ & 0 \\
\hline & Biomass* & 0 & & 0 & $0.5( \pm 0.2)$ & 0 \\
\hline \multirow[t]{2}{*}{ G. bondari } & No. Indiv. $\mathrm{m}^{-2}$ & 0 & & 0 & $3.2( \pm 1.1)$ & 0 \\
\hline & Biomass* & 0 & & 0 & $0.5( \pm 0.2)$ & 0 \\
\hline \multirow[t]{2}{*}{ Total No. earthworms $\mathrm{m}^{-2}$} & & $6.4 \mathrm{a}$ & & 0 & $6.4 \mathrm{a}$ & 0 \\
\hline & & \multicolumn{5}{|c|}{ Monoliths $(40 \times 40 \mathrm{~cm})$} \\
\hline \multirow[t]{2}{*}{ Glossoscolex spp.** } & No. Indiv. $\mathrm{m}^{-2}$ & $6.4( \pm 3.6)$ & & 0 & $2.0( \pm 1.2)$ & 0 \\
\hline & Biomass & $0.1( \pm 0.0)$ & & 0 & $0.1( \pm 0.0)$ & 0 \\
\hline \multirow[t]{2}{*}{ Glossoscolex sp. 1} & No. Indiv. $\mathrm{m}^{-2}$ & 0 & 4.0 & $( \pm 2.4)$ & $20.0( \pm 8.2)$ & $16.0( \pm 6.2)$ \\
\hline & Biomass & 0 & 0.3 & $( \pm 0.1)$ & $1.1( \pm 0.5)$ & $1.7( \pm 0.5)$ \\
\hline Total No. earthworms $\mathrm{m}^{-2}$ & & $6.4 \mathrm{~b}$ & & $4.0 \mathrm{~b}$ & $22.0 \mathrm{a}$ & $16.0 \mathrm{a}$ \\
\hline
\end{tabular}

* Biomass total fresh weight $\left(\mathrm{g} \mathrm{m}^{-2}\right) ;{ }^{* *}$ Imatures. Means followed by the same letter in each line do not differ $(P<0.05)$ by the LSD test.

active on the soil surface. Nonetheless, the formaldehyde extraction method is toxic to plants (Caballero, 1976) and is also carcinogenic, and its use as an extractor might become prohibited by law (Schmidt et al., 2001).

Nevertheless, the use of formaldehyde (Formol method) was necessary to effectively evaluate $A$. corticis populations in the four areas. This rapidly moving species was not adequately collected using the monolith methods, probably because of its rapid escape capability as the samples are being dug out. The highest total fresh biomass values $\left(\mathrm{g} \mathrm{m}^{-2}\right)$ were obtained with the formaldehyde and larger monolith (40 $\times 40 \mathrm{~cm}$ ) samples (Figure 1). With formalin, high biomass values were mostly due to $A$. corticis, while in the larger monoliths, it was mostly due to Glossoscolex sp.2.
Although handsorting soil monoliths adequately collected most soil-dwelling Glossoscolex species, neither of the two monolith sizes were adequate to collect the surface-active Amynthas and Urobenus species (Table 2 and Figure 1). Furthermore, using the TSBF method, no earthworms were collected in both $\mathrm{R}$ and NPF. But when the monolith size was increased to 40 $\times 40 \mathrm{~cm}$, more Glossoscolex individuals were collected (Figure 1), also increasing earthworm biomass recovered (Table 2).

Native forests (particularly when well preserved) generally tend to have higher earthworm biodiversity than human-altered ecosystems (Fragoso et al., 2006). This is generally due to the greater variability and availability of different food resources, and the absence of noxious perturbations (Decaëns et al., 1998; Correia \& Andrade, 1999; Ponge et al., 1999). 


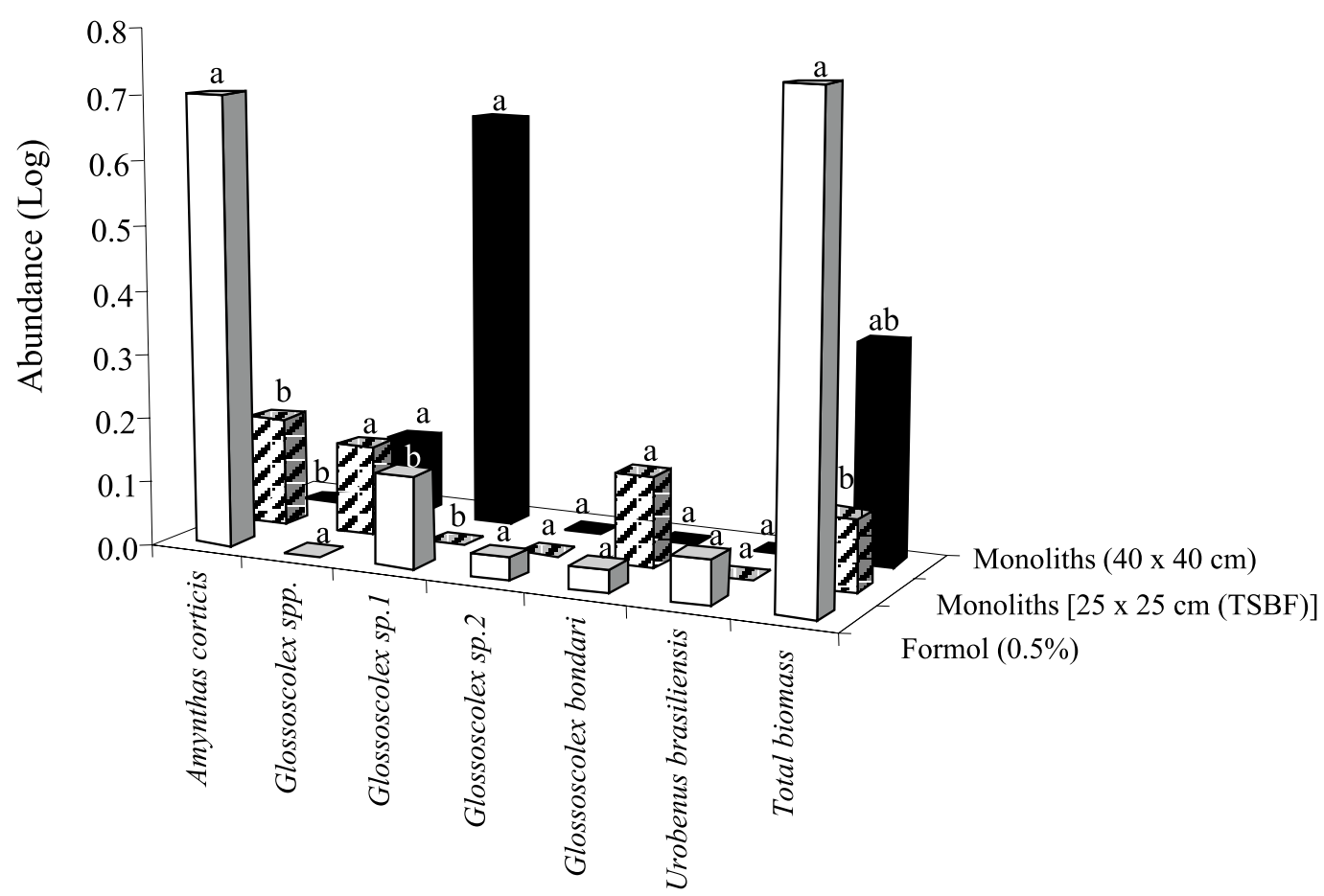

Figure 1 - Abundance (Log of the number of earthworms $\left.\mathrm{m}^{-2}\right)$ of each species of earthworms collected by Formol $(0.5 \%)$, small $(25 \times 25$ $\mathrm{cm})(\mathrm{TSBF})$ and large monolith $(40 \times 40 \mathrm{~cm})$ methods, combining results from the four sample sites with Araucaria in August 2005, Campos do Jordão, SP, Brazil. Values shown are means of five replicates from each site. Means followed by the same letters within each column do not differ $(P<0.05)$ by the LSD test. SD $=$ Standard deviation. Amynthas corticis (SD: 0.52); Glossoscolex spp. = (imatures) (SD: 0.23); Glossoscolex sp.1 (SD: 0.63); Glossoscolex sp.2 (SD: 0.01); Glossoscolex bondari (SD: 0.14); Urobenus brasiliensis (SD: 0.02); Total biomass = Log biomass total fresh weight $\left(\mathrm{g} \mathrm{m}^{-2}\right.$, SD: 0.51).

In the present study, NF, RF and R all had three species, while NPF had only two species. However, species composition among the sites was different; Glossoscolex sp.1 was not found in NF, while Glossoscolex sp.2 was found only in NF and $G$. bondari only in RF. However, the juvenile Glossoscolex collected by hand sorting in NF and RF may have belonged to any of the three species in this genus. $U$. brasiliensis was not found in the burned sites, indicating its probable sensitivity to this practice (at least in short time-frames).

The greater abundance of exotic earthworms in the NF may be due to the preference of A. corticis for the richer soil in this forest and less disturbance in this site. The species may have invaded the region and the Park's forests when roads and trails were built to harvest Araucaria trees before the middle of the $20^{\text {th }}$ century. Many exotic plant species brought from $\mathrm{Eu}-$ rope and other areas were planted throughout the Campos do Jordão region, and this species may have come in the potted soil of these plants. Furthermore, the soil used to grow seedlings for reforestation often contain Amynthas spp. and other exotic earthworm species (G. Brown, personal communication).
Kalisz \& Dotson (1989) demonstrated that forests previously disturbed by timber or agricultural exploitation showed greater abundance of exotic earthworm species, while native earthworms predominated in undisturbed forests. Likewise, anthropic intervention favored the invasion by exotic earthworm species in areas where they did not exist (Gundale et al., 2005). Invasion by exotic species is not only due to human activities, but also to their rapid dispersal (especially on the soil surface) and ecological plasticity, enabling these worms to colonize many different kinds of habitats, even the less favorable ones.

Little is known of the potential impacts, positive and/or negative, of these exotic species on the Araucaria forest ecosystem, its soil processes and biodiversity. Amynthas spp. invasion is known to have significant impacts on soil carbon losses, $\mathrm{N}$ mineralization and microbial communities (Burtelow et al., 1998; Li et al., 2002; Bohlen et al., 2004). Futher work is necessary on this topic, especially considering the extent of exotic earthworm distribution and invasions in Brazilian soils (Brown et al., 2006).

Therefore, although NF was little disturbed, the presence of exotic species in this forest fragment 
demonstrates an important past (and present) disturbance in the NF area caused by human and earthworm-induced modifications in this native environment. The extent of invasion of native Araucaria forests by exotic species still remains unknown. Public policies must be developed and strengthened, and more suitable management and conservation practices must be employed to avoid such invasions in native Brazilian forests.

\section{Cluster analysis}

Figures $2 \mathrm{~A}$ and $2 \mathrm{~B}$ show the dendrograms obtained by cluster analysis with the Formol method, where numbers on the vertical axis represent the Euclidean distance rescaled from 0 to 120 , and the horizontal axis shows the study sites (Figure 2A) and the most important species that generated the clusters (Figure 2B). A smaller linkage distance and greater similarity was verified between R and NPF by the Formol method, forming a cluster that was separated
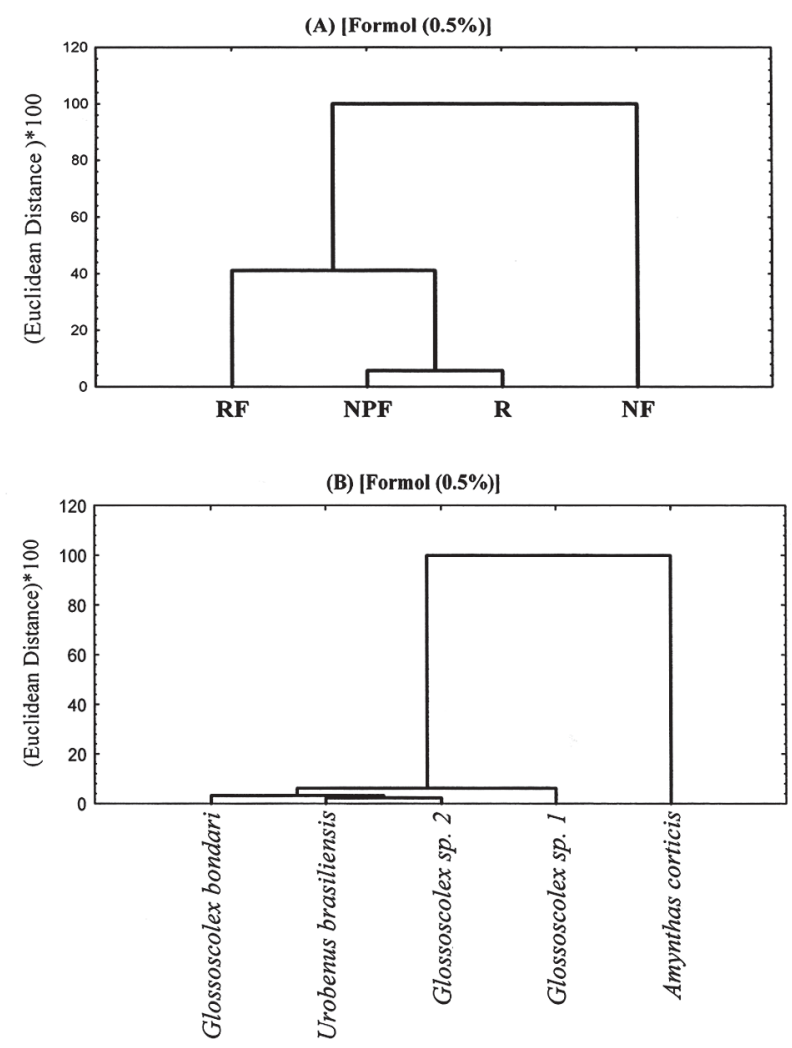

Figure 2 - Dendrograms obtained by cluster analysis, discriminating by "Euclidean Distance" the four sample sites (A) and the earthworm species present (B), sampled using the Formol $(0.5 \%)$ method. Samples were taken in a natural forest (NF), introduced forest (R), forest impacted-by-fire (RF) and native grass pasture with native Araucaria trees submitted to an intense accidental fire in September 2004 (NPF). Campos do Jordão, SP, August 2005. from the other sites, especially NF (Figure 2A). This site showed a greater linkage distance (was isolated from the other three areas), related to the abundance and effectiveness of the collection method. Formol was very effective in extracting $A$. corticis, which was separated from the other species by the cluster analysis (Figure 2B). All the remaining species were very similar among themselves and showed smaller linkage distances.

When the TSBF method was used in order to verify the similarity between sample sites (Figure 3A), the result was similar to that obtained with the formaldehyde. Furthermore, A. corticis was again isolated from the other species (Figure 3B). However, with the larger monoliths, the internal arrangement of sites (Figure 4A) was different: NF and R formed a separate cluster from the other two areas where accidental fires had occurred (NPF and RF). Furthermore, the species Glossoscolex sp.1 was isolated from the other

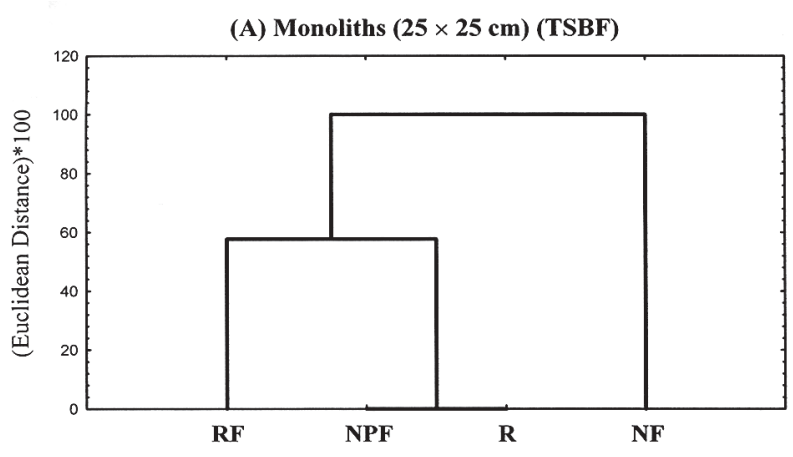

(B) Monoliths $(25 \times 25 \mathrm{~cm})($ TSBF $)$

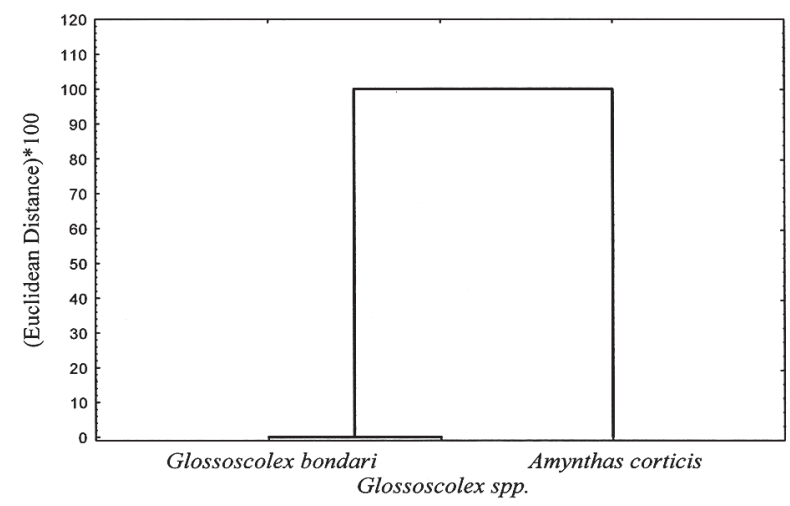

Figure 3 - Dendrograms obtained by cluster analysis, discriminating by "Euclidean Distance" the four sample sites (A) and the earthworm species present (B), sampled using the small $(25 \times 25 \mathrm{~cm})$ monolith (TSBF) method. Samples were taken in a natural forest (NF), introduced forest (R), forest impactedby-fire (RF) and native grass pasture with native Araucaria trees submitted to an intense accidental fire in September 2004 (NPF). Campos do Jordão, SP, August 2005. 


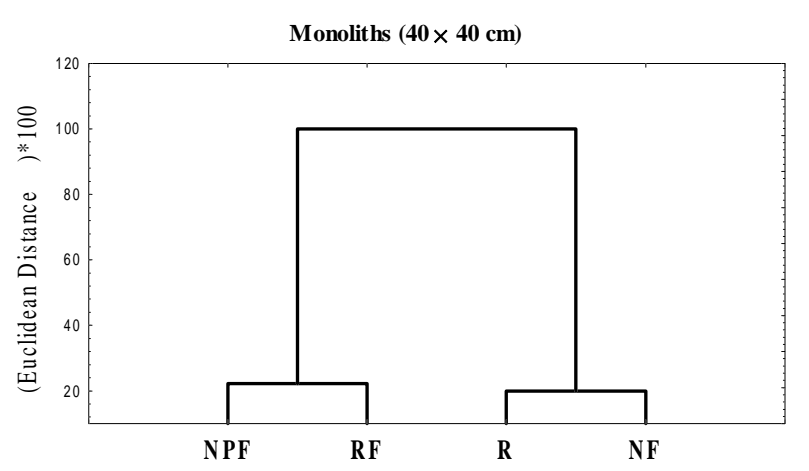

Figure 4 - Dendrogram obtained by cluster analysis, discriminating by "Euclidean Distance" the four sample sites using the large $(40 \times 40 \mathrm{~cm})$ monolith $(\mathrm{TSBF})$ earthworm collection method. Samples were taken in a natural forest (NF), introduced forest (R), forest impactedby-fire (RF) and native grass pasture with native Araucaria trees submitted to an intense accidental fire in September 2004 (NPF). Campos do Jordão, SP, August 2005.

earthworm species, due to the greater abundance of this species extracted by this method (Figure 1 and Table 2). Therefore, the cluster analyses established differences between the sample methods in terms of earthworm species and sample site grouping, reinforcing the importance of this tool for discriminating treatment effects and their impacts on earthworm communities.

\section{Principal components analysis (PCA)}

The result of the PCA for the Formol method showed a polarization of $A$. corticis abundance and total earthworm biomass with that of the remaining species (Figure 5A). Axis 1 and 2 explain 37\% and $33 \%$ of total data variability, respectively. Differently from the cluster analysis, a similarity was observed between RF and NF, as both sites had greater proportions of A. corticis. The other earthworm species did not show any association and contributed very little to separate the sample sites (Figure 5A).

For the TSBF method $(25 \times 25 \mathrm{~cm}), \mathrm{RF}$ and NF were opposed to each other and A. corticis was associated only to NF (Figure 5B). However, this method was not as effective as the other methods in separating the sites: Axis 1 and 2 explain only $11 \%$ and $10 \%$, respectively, of the total data variance. The larger monoliths were more effective than the TSBF method in separating the sites: Axis 1 and 2 explain $42 \%$ and $8 \%$ of the data variation, respectively. NPF and RF showed a strong association with Glossoscolex sp.1 (Figure 5C), indicating the possible greater resistance of this species to accidental fires.

Therefore, in order to properly characterize earthworm abundance, biomass and species compo-
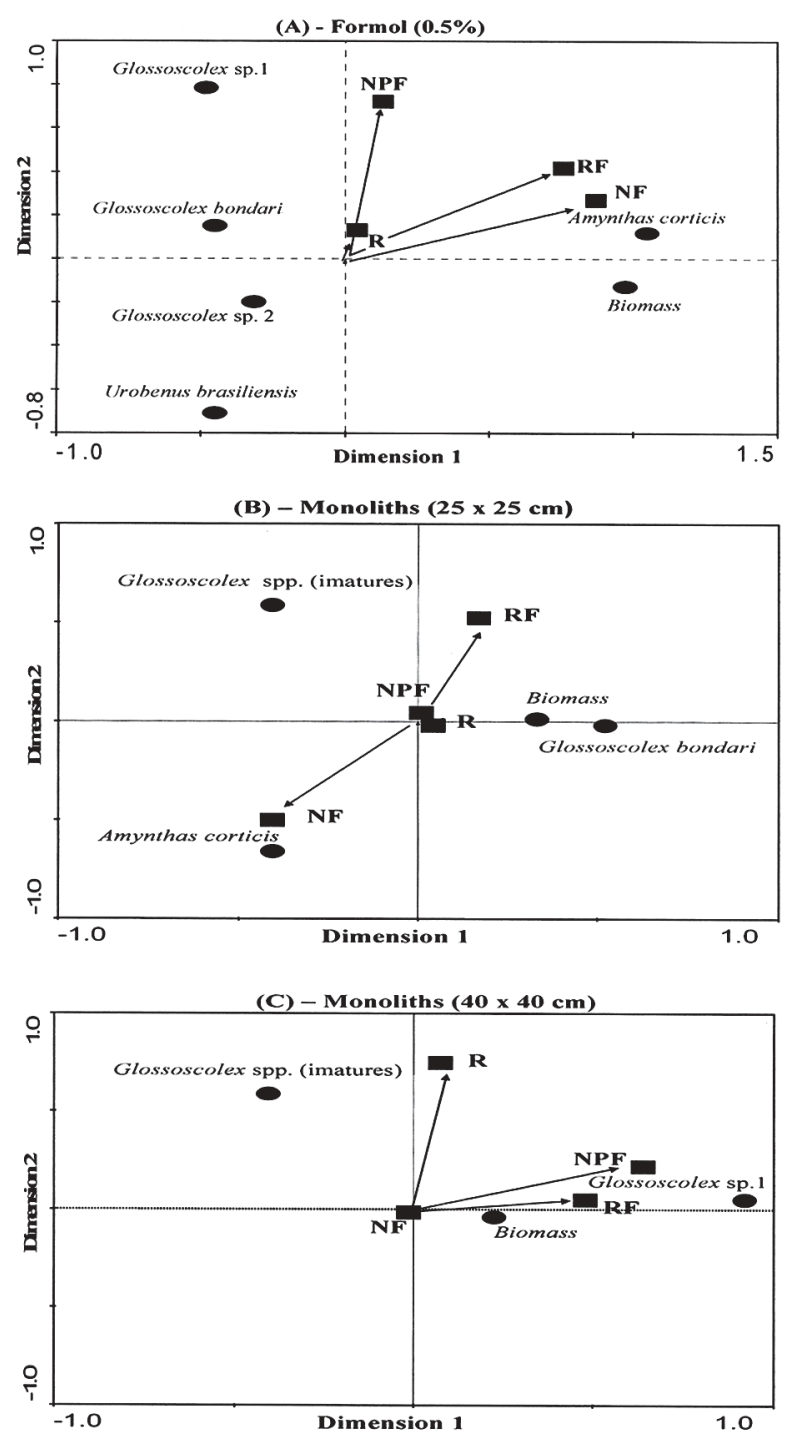

Figure 5 - Relation between dimensions 1 and 2 of the principal component analysis (PCA), discriminating sample sites ( $\square$ ) and earthworm species ( ), collected using (A) the Formol $0.5 \%$, (B) small $(25 \times 25 \mathrm{~cm})(\mathrm{TSBF})$ and $(\mathrm{C})$ large $(40 \times 40 \mathrm{~cm})$ monolith methods. Samples were taken in a natural forest (NF), introduced forest (R), forest impacted-by-fire (RF) and native grass pasture with native Araucaria trees submitted to an intense accidental fire (NPF). Campos do Jordão, SP, August 2005. Biomass: Biomass total fresh weight $\left(\mathrm{g} \mathrm{m}^{-2}\right)$.

sition in Araucaria forests, a combination of methods including both Formol and larger handsorted soil monoliths should be employed, thus ensuring a rapid collection of surface-active (A. corticis, U. brasiliensis) and within-soil (endogeic) species (mainly Glossoscolex spp.). These results confirm those of Caballero (1976), who concluded that the best monolith size to evaluate earthworm abundance measured $60 \times 60 \mathrm{~cm}$, to a depth of 0.5-0.6 $\mathrm{m}$, and that smaller $(30 \times 30 \mathrm{~cm})$ 
monoliths were inadequate for this purpose. This is likely because of the relatively large $(9-44 \mathrm{~cm})$ earthworms present at her sample sites in northwestern São Paulo state.

\section{CONCLUSIONS}

Earthworm biomass, abundance and diversity were sensitive indicators of human interventions in Araucaria forests. However, the type and effectiveness of the collection methods, number of samples per site, and manner by which data are analyzed statistically must be considered carefully in studies of human impacts on earthworm communities in Brazilian forests. The following additional conclusions can be made from this study: (i) Density, diversity and biomass of earthworms collected in Araucaria forests were affected by natural and anthropogenic disturbance, and by the sampling method used; (ii) The dilute Formol method was more effective in collecting A. corticis and in assessing total earthworm biomass, while the handsorting of soil monoliths was more effective in capturing various Glossoscolex species; (iii) In order to properly characterize earthworm abundance and biomass in forest systems that have undergone anthropic pressure, both the Formol and large $(40 \times 40 \mathrm{~cm})$ monolith methods should be employed, to ensure rapid collection of surface-active species (Amynthas, Urobenus) and those living in the soil (Glossoscolex spp.).

\section{ACKNOWLEDGEMENTS}

D. Baretta, G.G. Brown, and E.J.B.N. Cardoso thank the CNPq for fellowship support. S.W. James acknowledges the support of Embrapa, Prodetab and NSF for his visits to Brazil. The authors also wish to thank: BIOTA/FAPESP for funding the project (No. 01/ 05146-6); IBAMA for the collection permit (No. 02027.002353/05-94); the Parque Estadual de Campos do Jordão employees for their assistance during collections; ESALQ/USP technicians Denise Mescolotti, Dorival Grisotto, and Luis F. Baldesin, and graduate students Rafaela F. Neroni (ESALQ/USP) and Marie L.C. Bartz Cruz (UEM) for their help.

\section{REFERENCES}

ANDERSON, J.M.; INGRAM, J.S.I. Tropical soil biology and fertility: a handbook of methods. 2.ed. Wallingford: CAB International, 1993. $171 \mathrm{p}$.

BAKER, G.H. Formalin-expulsion of earthworms (Lumbricidae) from irish peat soils. Soil Biology and Biochemistry, v.17, p.113-114, 1985.

BARETTA, D.; MAFRA, Á.L.; SANTOS, J.C.P.; AMARANTE, C.V.T.; BERTOL, I. Análise multivariada da fauna edáfica em diferentes sistemas de preparo e cultivo do solo. Pesquisa Agropecuária Brasileira, v.41, p.1675-1679, 2006.
BENHAM, W.B. Studies on earthworms. Quarterly Journal of Microscopic Science, v.27, p.77-108, 1887.

BOHLEN, P.J.; SCHEU, S.; HALE, C.M.; MCLEAN, M.A.; MIGGE, S.; GROFFMAN, P.M.; PARKINSON, D. Non-native invasive earthworms as agents of change in northern temperate forests. Frontiers in Ecology and the Environment, v.2, p.427-435, 2004.

BROWN, G.G.; JAMES, S.W.; PASINI, A.; NUNES, D.H.; BENITO, N.P.; MARTINS, P.T.; SAUTTER, K.D. Exotic, peregrine and invasive earthworms in Brazil: Diversity, distribution and effects on soils and plants. Caribbean Journal of Science, v.42, p.331-338, 2006.

BURTELOW, A.E.; BOHLEN, P.J.; GROFFMAN, P.M. Influence of exotic earthworm invasion on soil organic matter, microbial biomass and denitrification potential in forest soils of the northeastern United States. Applied Soil Ecology, v.9, p.197202, 1998.

CABALLERO, M.E.S. Bionomia de Oligochaeta terrestres da Região Norte Ocidental do Estado de São Paulo I- Métodos. Ciência e Cultura, v.28, p.762-765, 1976.

CHAN, K-Y.; MUNRO, K. Evaluating mustard extracts for earthworm sampling. Pedobiologia, v.45, p.272-278, 2001.

CORREIA, M.E.F.; ANDRADE, A.G. Formação de serapilheira e ciclagem de nutrientes. In: SANTOS, G.A.; CAMARGO, F.A.O. Fundamentos da matéria orgânica do solo: ecossistemas tropicais e subtropicais. Porto Alegre: Gênesis, 1999. p.197-225.

DECAËNS, T.; DUTOIT, T.; ALARD, D.; LAVELLE, P. Factors influencing soil macrofaunal communities in post-pastoral successions of western France. Applied Soil Ecology, v.9, p.361367, 1998.

DECAËNS, T.; ROSSI, J.P. Spatio-temporal structure of earthworm community and soil heterogeneity in a tropical pasture. Ecography, v.24, p.671-682, 2001.

DICKEY, J.B.; KLADIVKO, E.J. Sample unit size and shapes for quantitative sampling of earthworm populations in crop lands. Soil Biology and Biochemistry, v.21, p.105-111, 1989.

EDWARDS, C.A. The assessment of populations of soil-inhabiting invertebrates. Agriculture, Ecosystems and Environment, v.34, p.145-176, 1991.

EKSCHMITT, K. Population assessments of soil fauna: General criteria for the planning of sampling schemes. Applied Soil Ecology, v.9, p.439-445, 1998

EVERITT, B.S. Cluster analysis. New York: John Wiley e Sons Inc., 1993. 170p

FRAGOSO, C.; LAVELLE, P.; BLANCHART, E.; SENAPATI, B.K.; JIMÉNEZ, J.J.; MARTÍNEZ, M.A.; DECAËNS, T.; TONDOH, J. Earthworm communities of tropical agroecosystems: Origin, structure and influence of management practices. In: LAVELLE, P.; BRUSSAARD, L.; HENDRIX, P. (Ed.). Earthworm management in tropical agroecosystems. Wallingford: $C A B$ International, 2006, p.27-55.

FRAKES, W.B.; YATES, R.B. Information retrieval: Data structures \& algorithms. New Jersey: Prentice Hall, 2000. 497p.

GILLER, K.E.; BEARE, M.H.; LAVELLE, P.; IZAC, A.-M.N.; SWIFT, M.J. Agricultural intensification, soil biodiversity and agroecosystem function. Applied Soil Ecology, v.6, p.3-16, 1997.

GUERRA, M.P.; SILVEIRA, V.; REIS, M.S.; SCHNEIDER, L. Exploração, manejo e conservação da araucária (Araucaria angustifolia). In: SIMÕES, L.L.; LINO, C.F. Sustentável Mata Atlântica: A exploração de seus recursos florestais. São Paulo: SENAC, 2002. p.85-102.

GUNDALE, M.J.; JOLLY, W.M.; DELUCA, T.H. Susceptibility of a Northern hardwood forest to exotic earthworms invasion. Conservation Biology, v.19, p.1075-1083, 2005.

HUECK, K. As florestas da América do Sul. São Paulo: Polígono, 1972. 466p.

JAMES, S.W.; BROWN, G.G. Earthworm ecology and biodiversity in Brazil. In: MOREIRA, F.M.S.; SIQUEIRA, J.O.; BRUSSAARD, L. (Ed.). Soil biodiversity in Amazonian and other Brazilian ecosystems. Wallingford: CAB International, 2006. p.56-116. 
JIMÉNEZ, J.J.; LAVELLE, P.; DECAËNS, T. The efficiency of soil hand-sorting in assessing the abundance and biomass of earthworm communities. Its usefulness in population dynamics and cohort analysis studies. European Journal of Soil Biology, v.42, p.S221-S230, 2006.

JONGMAN, R.H.G. Data analysis in community and landscape ecology. Cambridge: Cambridge University Press, 1995. 299p.

JOSCHKO, M.; FOX, C.A.; LENTZSCH, P.; KIESEL, J.; HIEROLD, W.; KRÜCK, S.; TIMMER, J. Spatial analysis of earthworm biodiversity at the regional scale. Agriculture, Ecosystems and Environment, v.112, p.367-380, 2006.

KALISZ, P.J.; DOTSON, D.B. Land-use history and the occurrence of exotic earthworms in the mountains of Eastern Kentucky. American Midland Naturalist, v.122, p.288-297, 1989.

KINBERG, J.G.H. Annulata nova. Ofversigt af Kongliga Vetenskaps-Akademiens Forhandlingar, v.23, p.97-103, 1867.

LAVELLE, P.; MAURY, M.E.; SERRANO, V. Estudio cuantitativo de la fauna del suelo en la región de Laguna Verde, Veracruz: Época de lluvias. Instituto de Ecología de México Publicaciones v.6, p.75-105, 1981.

LAVELLE, P.; SPAIN, A.V. Soil ecology. Dordrecht: Kluwer Academic, 2001. 654p.

LI, X.; FISK, M.C.; FAHEY, T.J.; BOHLEN, P.J. Influence of earthworm invasion on soil microbial biomass and activity in a northern hardwood forest. Soil Biology and Biochemistry, v.34, p.1929-1937, 2002.

MICHAELSEN, W. Zur kenntnis einheimischer und ausländischer Oligochäten. Zoologische Jahrbücher Abteilung für Systematik, v.51, p.255-328, 1926.

MOREIRA, M.; BARETTA, D.; TSAI, S.M.; CARDOSO, E.J.B.N. Spore density and root colonization by arbuscular fungi in preserved or disturbed Araucaria angustifolia (Bert.) O. Ktze. ecosystems. Scientia Agricola, v.63, p.380-385, 2006.
PAOLETTI, M.G. The role of earthworms for assessment of sustainability and as bioindicators. Agriculture, Ecosystems and Environment, v.74, p.137-155, 1999.

PONGE, J.-F.; PATZEL, N.; DELHAYE. L.; DEVIGNE, E.; LEVIEUX, C.; BEROS, P.; WITTEBROODT, R. Interactions between earthworms, litter and trees in an old-growth beech forest. Biology and Fertility of Soils, v.29, p.360-370, 1999.

RAIJ, B. van; ANDRADE, J.C.; CANTARELLA, H.; QUAGGIO, J.A. Análise química para avaliação da fertilidade de solos tropicais. Campinas: Instituto Agronômico. 2001. 285p.

RAW, F. Estimating the earthworm population by using formalin. Nature, v.184, p.1661, 1959.

SAS Institute. SAS/STAT, Release 6.2. Cary: SAS Institute Inc., 1996.

SCHIMIDT, O.; CURRY, J.P.; HACKETT, R.A.; PURVIS, G.; CLEMENTS, R.O. Earthworm communities in conventional wheat-clover monocropping and low-input wheat-clover intercropping systems. Annals of Applied Biology, v.138, p.377-388, 2001.

STATSOFT INC. Statistica (data analysis software system), version 6. Tulsa, OK, USA, 2001.

TER BRAAK, C.J.F. Canonical correspondence analysis: a new eigenvector technique for multivariate direct gradient analysis. Ecology, v.67, p.1167-1179, 1986.

TER BRAAK, C.J.F.; SMILAUER, P. CANOCO reference manual and user's guide to Canoco for Windows: Software for canonical community ordination (version 4). , New York: Microcomputer Power, 1998.

Received September 29, 2006

Accepted April 26, 2007 